\section{Entrepreneurial Competencies and Strategic Behavior: a Study of Micro Entrepreneurs in an Emerging Country}

\author{
Gustavo Behling ${ }^{1,+(D)}$ \\ ${ }^{1}$ Universidade do Vale do Itajaí, Itajaí, SC, Brazil \\ Fernando César Lenzi $2, \Omega(D)$ \\ ${ }^{2}$ Universidade do Vale do Itajaí, Itajaí, SC, Brazil
}

\section{ABSTRACT}

The purpose of this paper is to analyze the relationship between the entrepreneurial competencies and the strategic behavior patterns of entrepreneurs in response to the social and economic environment in which they operate, taking into consideration limitations that are common to emerging countries. The study takes a quantitative approach with a survey of 211 Individual Micro Entrepreneurs (IME) operating in the Brazilian state of Santa Catarina. The results demonstrated that there were differences between mean scores for the entrepreneurial competencies when compared across the entrepreneurs' strategic behavior types. Moreover, entrepreneurs who were Reactors possessed a mean of 6 out of the ten entrepreneurial competencies, Defenders had 7.97, Analyzers had 8.38, and Prospectors had 8.56. The paper reveals which competencies are most likely to be associated with each strategic behavior type. The findings also indicate that entrepreneurial competencies can impact the adoption of more consistent business strategies, contributing to actions that respond to unstable social and economic scenarios.

Keywords: Entrepreneurship, Strategy, Entrepreneurial competencies, Strategic behavior.

\section{INTRODUCTION}

The study of entrepreneurship has its origins in studies by economists such as Richard Cantillon (1755), Jean Baptiste Say (1803), and Joseph Schumpeter (1949), but in the 1960s and 1970s behaviorist thinkers entered the debate, publishing work that contrasted with the rationalist view that had hitherto, dominated. These authors (McClelland 1965a; Timmons, 1978) did not believe that the complexity of entrepreneurial behavior could be satisfactorily explained by strictly economic factors, considering the behavioral characteristics of entrepreneurs in this field of study.

David McClelland (1965a; 1965b; 1967) was one of the most influential of these researchers and his work has become seminal. Part of his work resulted in the identification of a set of behavioral
Corresponding author:

† Universidade do Vale do Itajaí, Itajaí, SC, Brazil

E-mail: behling@univali.br

$\Omega$ Universidade do Vale do Itajaí, Itajaí, SC, Brazil

E-mail: lenzi@univali.br

Received: $12 / 08 / 2017$.

Revised: 03/14/2018.

Accepted: 07/23/2018.

Published Online: 03/27/2019.

DOI: http://dx.doi.org/10.15728/bbr.2019.16.3.4 
characteristics, which Cooley (1990) optimized some years later, resulting in a model composed of ten entrepreneurial competencies that were considered to be associated with superior entrepreneurial performance.

In order to adapt in a consistent manner to the environment, it is important for entrepreneurs to be alert, updated and to effectively use information from the external environment in their decision-making (CANCELLIER, 2013). Entrepreneurs with a greater set of competencies have characteristics that they employ in complex situations, turning them into space to undertake (FEUERSCHÜTTE; GODOI, 2008), since the entrepreneurial skills reinforce the strategic perception, allowing the glimpse of opportunities for innovation, business growth and the development of better capabilities from organizational resources (SOUZA; TEIXEIRA, 2013). Thus, entrepreneurial skills are expressed through the ability not only to identify, but also to exploit opportunities in a specific context (LANS et al., 2008).

From the voluntaristic perspective (ASTLEY; VAN DE VEN 2005), the performance of organizations is a result of entrepreneurs' capacity to formulate strategies that contemplate and align the organization to ever more complex and dynamic changes in the environment, such as the changes faced by firms today. Miles and Snow (1978) studied the strategic behavior of organizations using a voluntaristic approach and developed a typology that offers a key to understand the way organizations adapt, condensing their behavior patterns to four behavioral types, which would answer questions such as definition of target markets, organizational structure, and operational decisions in different ways. They named these behavior types the Prospector, the Analyzer, the Defender, and the Reactor (Table 1).

This study is designed to empirically test for relationships between an entrepreneurs' entrepreneurial competencies (COOLEY, 1990) and the strategic behavior (MILES; SNOW, 1978) they adapt their businesses to the environments in which they operate. Mitchelmore and Rowley (2010) consider that there is a direct relationship between the entrepreneur's competencies and the firm's strategy and, according to Sánchez (2012), entrepreneurial competencies enable entrepreneurs to formulate higher quality strategies. Sarwoko (2016), on the other hand, argues that entrepreneurs' competencies lead small and medium companies to a larger capacity and strategic vision, which can affect performance and growth strategies. This paper is a response to the problem that, while on one hand these claims appear to be very reasonable, on the other there is a need for empirical studies that can facilitate the understanding of this link, which is the gap that this research is intended to explore.

In order to test for the existence of this relationship, this study takes a quantitative approach, employing a survey of 211 Individual Micro Entrepreneurs (IME) operating in the state of Santa Catarina, in the South of Brazil. The Individual Micro Entrepreneur category was created recently as part of a government policy to regulate a series of economic activities that were typically conducted informally and so encourage those engaged in them to register their businesses. Analyses are conducted using Analysis of Variance (ANOVA) with the objective of answering the primary research question: are there differences between the set of entrepreneurial competencies possessed by Individual Micro Entrepreneurs that are associated with the strategic behaviors they adopt?

The remainder of this paper has the following structure: the next section presenting the theoretical background on entrepreneurial competencies and strategic behavior is followed by a section describing the methodological procedures employed and a results section, and then the paper closes with a discussion and some final comments. 


\section{LITERATURE REVIEW}

This review discusses the fundamental concepts and the most important contributions that form the foundation for this study, starting with entrepreneurial competencies and moving on to a discussion of the implications of Miles and Snow's (1978) seminal study of strategic behavior.

\subsection{ENTREPRENEURIAL COMPETENCIES}

The term competent is commonly used to describe someone who is qualified to perform a certain activity (FLEURY; FLEURY 2001). While common sense appears to have no difficulties characterizing a person's competence, Feuerschütte and Godoi (2008) point out that scientific interpretations of the subject have emerged from different fields of human and social sciences and the resulting definitions, with their roots in different contexts, are inevitably expressions of diverging views and concepts.

According to Fleury and Fleury (2001), studies investigating competencies can be traced back to David McClelland's publication of "Testing for Competence rather than Intelligence" in 1973, in which he links competence to superior performance of a task. However, Fleury and Fleury (2001) state that as studies advanced it became clear that competence is on a higher level, something that cannot be limited to a stock of theoretical and empirical knowledge and does not remain encapsulated within the task itself. These advances were primarily achieved through work by the French authors Zarifian and Le Boterf (FLEURY; FLEURY, 2001).

Le Boterf (2003) emphasizes the importance of context to the concept of competencies. He defines competence as the practice of what one knows in a given situation, influenced by work relations, organizational culture, and other factors. Competence should therefore, be translated into action, by the mobilization of knowledge in differing circumstances. Along the same lines, Zarafian (2004) sees competence as being made up of three mutually complementary elements: people taking the initiative and taking responsibility for professional situations with which they are faced; practical intelligence of situations that is supported by acquired knowledge and transforms that knowledge as the diversity of situations increases; and the capacity to mobilize networks of actors around the same situations, sharing challenges and accepting areas of responsibility. He therefore defines competence as initiative and as taking responsibility for problems and events faced in professional situations.

It is important to point out that, from the point of view of the organization, competencies must add value (FLEURY; FLEURY 2001, LENZI, 2008). This interpretation refers to what several authors term as "delivery". They consider that competent people will skillfully mobilize their theoretical knowledge and the resources available to obtain superior results for organizations (COOLEY 1990; FLEURY; FLEURY, 2001; DUTRA, 2001; LENZI, 2008; LENZI et al., 2012). For Nassif, Andreassi, and Simões (2011), competence can be considered a top level of a person's characteristics, since it encompasses different personality traits, skills and knowledge, influenced by experience, training, education, family traits, and other demographic variables.

Mitchelmore and Rowley (2010) affirm that research into entrepreneurial competencies concentrates on personal features and characteristics of the entrepreneur, such as the knowledge and skills that enable an entrepreneur to run a business competently. As such, Mitchelmore and Rowley's concept of the entrepreneurial competencies is as a group of characteristics that are relevant to successful entrepreneurship and are frequently associated with the development of new and small businesses, although there is also growing interest in the competencies of corporate entrepreneurs. 
Ahmad et al. (2010) have stressed the importance of understanding the role played by entrepreneurs' knowledge, skills, attitudes, and behavior and the impact that these personal characteristics have on firm performance. They conducted an empirical study of 212 SMEs in Malaysia and demonstrated that entrepreneurs' competencies had a direct and substantial impact on firms' success.

Zampier and Takahashi (2011) expanded the concept, defining entrepreneurial competence as a body of knowledge, area or skill, personal qualities or characteristics, attitudes or views, motivations or orientations that can contribute to reasoning or effective business activity, enabling an individual to enact actions and strategies for social value creation. For Nassif, Andreassi, and Simões (2011), studies of the entrepreneur must include attempts to understand these social actors' actions, inside or outside of organizations, in order to understand which competencies drive their activities.

Entrepreneurial competence also includes factors related to entrepreneurs' motivation, such as the need for achievement, independence, and personal growth, among others, combined with personal characteristics such as innovation, creativity, risk propensity, and proactivity (JAIN, 2011). For Sanchéz (2012), entrepreneurship competencies make individuals more alert to environmental conditions and enhance their ability to adapt internal resources to gain competitive advantage.

Chell (2013) points out that competencies is a very comprehensive construct, encompassing skills and a variety of attributes that are relevant to performance of a specific task; competencies are therefore goal-oriented. As Lizote and Verdinelli (2014) point out, entrepreneurial competencies can be understood as a construct that encompasses different traits of personality, skills, and knowledge.

Middleton and Donnellon (2014) use the terms "know how, know what and know why" to refer to these traits and to the entrepreneurial competencies. They define "know what" as a person's cognitive knowledge about what to do in a given situation, "know how" is a person's functional capabilities, and "know why" encompasses the entrepreneur's attitudes, values, and behavior, representing personal engagement and legitimization of the entrepreneurial activity. For Bamiatzi et al. (2015) entrepreneurial competencies are a specific group of competencies relevant to the exercise of entrepreneurship and the development of small and new businesses. Sarwoko (2016) argues that entrepreneurial competencies affect the ability to create growth strategies and therefore, business performance.

With respect to development of entrepreneurial competencies, Lenzi (2008) claims that in the same way that a person can polish their competencies, entrepreneurs can adapt their individual characteristics in order to develop an entrepreneurial competence. Ahmad et al. (2010) claim that entrepreneurs should develop their competencies as the first step towards the success of their enterprise.

In view of the importance of this subject to the entrepreneurial process, in the 1980s, the United States Agency for International Development (USAID) financed a study led by Lyle Spencer and David McClelland in three underdeveloped countries with the objectives of identifying the characteristics of successful businesspersons in Third World countries and developing training programs for entrepreneurial ventures. The study was conducted in Ecuador, in Latin America, Malawi in Africa, and India, in Asia (LENZI, 2008).

Cooley (1990) conducted another study, which was contracted by the United States agency for International Development and added a further three characteristics (goal setting, preference for moderate risk, and independence) to the twenty basic characteristics listed by Spencer and McClelland and then consolidated the twenty-three characteristics into ten entrepreneurial competencies, on the basis of combinations and overlapping of certain attributes. The final set of ten entrepreneurial competencies and their characteristic 
BBR

16,3

actions, as proposed by Cooley (1990), are described in Table 2, which also presents the results of the study.

Since Cooley's work (1990) resulted in a typology that offered a simple method for identifying entrepreneurial competencies, it received a great deal of academic interest (LENZI, 2008). Although possession of well-developed entrepreneurial competencies is not a guarantee of superior performance in management of a business, their development can undoubtedly contribute to formulation of more consistent organizational strategies.

\subsection{Strategic Behavior}

Studies of organizations and their adaptation to the external environment have resulted in the emergence of two distinct two points of view: determinism and voluntarism. According to Astley and Van de Ven (2005), the deterministic perspective focuses on the structural properties of the context in which an organization is operating and, within this paradigm, individual behavior is determined by environmental structural restrictions, to which organizations and their management can only react.

In contrast, from the voluntaristic point of view, individuals and organizations are autonomous agents, that are proactive and self-governed and as such are the basic units of analysis and the source of change in organizations. Within this paradigm, an organization's performance is seen as the result of its managers' capacity to formulate strategies and align the organization to changes in the environment in which it operates (this task may be more or less complex depending on the industry involved) and management must analyze a large number of variables before taking decisions (ASTLEY; VAN DE VEN, 2005).

This process of adaptation and the strategic choices it provokes are of fundamental importance to the organization's long-term sustainability. Pereira and Antonialli (2011) state that strategic behavior encompasses the process of organizational adaptation to environmental turbulence, involving the internal dynamic of the organization, i.e., the way in which firms align themselves to the external environment and the choices they make over time characterize their strategic behavior.

Firmly in the voluntaristic camp, Miles and Snow (1978) state that while context can indeed limit the maneuvers available to managers, it does not determine them, and they consider the executives' perception and actions to be equally important to define strategy. The authors stated that organizations act within these behavior patterns when they attempt to achieve alignment with the external environment. Miles et al. (1978) argue that by searching for these behavior patterns, it is possible to describe and even predict an organization's process of adaptation.

Considering this assumption, Miles and Snow (1978) developed a typology to facilitate understanding of organizations' adaptation processes, reducing organizational behavior patterns to four types: the Prospector, the Analyzer, the Defender, and the Reactor. These patterns of strategic behavior spring from the differences in how organizations respond to three problems: the entrepreneurial problem, or the problem of defining the product and target market that the firm will serve; the engineering problem, or development of a system capable to operationally solve the answer to the entrepreneurial problem, and the administrative problem, which is related to organizational structure. Together these three problems comprise what the authors termed as the Adaptive Cycle. According to Miles and Snow (1978), each of the behavior types has a characteristic response to the cycle, as described in Table 1.

As Ghobril and Morri (2009) have stated, the first three strategic types are considered aligned because, once a strategic objective has been defined in terms of product-market, the firm develops an appropriate response in technology, manufacturing, systems, processes, 
Table 1. Miles and Snow's (1978) Strategic Behavior Typology.

\begin{tabular}{ll}
\hline Strategic Behavior & Characteristics \\
\hline Prospector & $\begin{array}{l}\text { Prospectors constantly seek opportunities in new products and/or markets, } \\
\text { striving to pioneer. Their efforts to innovate can often compromise their short-term } \\
\text { profitability, but this is not a problem, since the organization and its managers bet } \\
\text { on future returns offered by their strategies. }\end{array}$ \\
& $\begin{array}{l}\text { Defenders restrict their scope of operations to a stable market or line of products, } \\
\text { over which they maintain domination through specialization. They stick to what } \\
\text { Defender }\end{array}$ \\
& $\begin{array}{l}\text { Analyzers analyze tendencies in the markets they do business in, only adopting } \\
\text { strategies that have already been successfully employed by other organizations. } \\
\text { Analyzer }\end{array}$ \\
& $\begin{array}{l}\text { They thus combine prospective and defensive characteristics, with the objective of } \\
\text { minimizing risks and maximizing opportunities for profit. }\end{array}$ \\
& Reactors merely respond to their external environments, only developing new \\
products or markets when threatened by other competitors, attempting to thereby, \\
avoid losing customers or profitability. They act as though they have no strategy \\
Reactive
\end{tabular}

Source: Author's elaboration.

and controls, so that the chosen strategy can be implemented adequately. They also point out that the performance of organizations that adopt one of these three types of behavior tends to be superior to that of Reactor firms, since these are slow to respond to market pressures, which makes them ineffective and unstable.

According to Gimenez et al. (1999), the two most contrasting categories are the Prospector, characterized by constant scanning for new markets, products, and processes, and the Defender, which focuses on restricted markets, in which it has a certain dominance. Analyzers' behavior is a hybrid of the two previous types, while Reactor organizations do not exhibit any relationship between strategy and structure.

Walker et al. (2003) consider that it is the environmental circumstances that will determine the most appropriate strategic behavior, i.e. the behavior that will result in better performance for the organization. These authors list six characteristics of environments that are favorable to Prospector organizations, as follows: (1) industries in initial phases of the product lifecycle; (2) market segments or niches that have not yet developed; (3) industries with emergent technology; (4) markets with few established competitors; (5) industries with structures in the process of evolution; and (6) industries in which market shares are highly concentrated. They consider that the inverse conditions favor Defender organizations, whereas the Analyzer behavior is appropriate in intermediate situations (WALKER et al., 2003).

As strong points of the typology created by Miles and Snow, Gimenez et al. (1999) highlight the possibility that the framework can be applied to studies of organizations of any size, in contrast with other strategy typologies, and the simplicity of fitting organization's strategic behavior to one of just four categories. The studies of Gardelin, Rossetto and Verdinelli (2013), Gallas et al. (2015) and Martins and Flores (2017) are examples of typology applications in small business empirical research.

In relation to the patterns of strategic behavior adopted more frequently in small companies, these research conflict about the results. The study by Gardelin, Rossetto and Verdinelli (2013), for example, carried out with small companies from different segments showed a predominance of Prospector behavior (40\% of the sample). In the research by Gallas et al. (2015), performed with small companies in the beauty and esthetics sector, the most frequent behavior is the Defender (32.4\% of the sample). Martins and Flores (2017), 
BBR

16,3

studying hotel managers presented another result, identifying that $40.80 \%$ of the sample adopts the Analyzer behavior. In spite of the differences, in all these studies, Reactive behavior was the least present, confirming the statements of Miles and Snow (1978).

Parnell (2013) argues that Miles and Snow's typologies remain among the most widely cited, tested, and refined in samples of both large organizations and SMEs. Indeed, the taxonomy has indeed been the subject of considerable academic attention from studies in the area of strategy and has been extensively tested in different organizational configurations and environments, demonstrating qualities in terms of coding and prediction. Andrews et al. (2008) comment that Miles and Snow's work provides one of the most comprehensive generic models of strategy that has been developed in the field of research in administration. Desarbo, Benedetto, and Song (2008) point to the model's resistance to time and state that even more than thirty years after its creation, the model is still widely accepted.

Having reviewed the relevant literature, a number of research questions were raised that need to be answered to improve the understanding of the relationship between entrepreneurs' competencies and the strategic behavior they adopt:

- Q1: Which competencies (and sets of competencies) are most present in the behavior of Individual Micro Entrepreneurs?

- Q2: What strategic behavior do these entrepreneurs adopt?

- Q3: Do higher mean scores for each competence and a larger set of developed competencies induce entrepreneurs to adopt more consistent strategic behavior?

- Q4: Which entrepreneurial competencies are associated with each of the strategic behavior types?

The methodological procedures were selected to answer these questions and the presentation and discussion of results follow this structure.

\section{RESEARCH METHODS}

This empirical study takes a quantitative approach, which is because of: a) the theoretical positions of the studies that provide its foundations (COOLEY, 1990; MILES; SNOW, 1978); b) its greater appropriateness to the objectives defined and; c) the sizable sample analyzed. The research objectives are descriptive and inferential, to the extent that it aims to establish relationships between constructs. In order to fulfill these objectives, the strategy chosen was a survey.

The population investigated is the Individual Micro Entrepreneur (IME) registered in the state of Santa Catarina (Brazil) and receiving credit conceded by the state's development agency (BADESC). Individual Micro Entrepreneurs are self-employed entrepreneurs who may employ a maximum of one employee and have a maximum annual turnover of 60 thousand BRL. Being registered as an IME offers the chance to obtain legitimacy for previously informal activities and series of benefits such as the exemption from federal taxes, access to social security, simplification of the red tape involved in the registration of firms and the declaration of fiscal data and access to banking services and sources of credit that are restricted to companies and the offer of lower interest rates.

Before their registration, these people worked informally, many of them have little education and the new system allowed them to become self-sufficient entrepreneurs. The objective of identifying entrepreneurial competencies in these people and the strategic behavior they adopt in their business activities is an attempt to understand how these incipient businesses are managed. Focusing on the population of Individual Micro Entrepreneurs and how they manage their activities could reveal evidence of possible management failures in a high number of new businesses, which justifies the choice of this particular object of study. 
After the law regulating (and creating) the status of Individual Micro Entrepreneur was approved, 132,408 entrepreneurs registered in the state of Santa Catarina, and 15,838 of them took advantage of credit offered by BADESC. For the purposes of this study, the sampling frame chosen was the population of individual micro entrepreneurs registered in the region of the Associação dos Municípios da Foz do Rio Itajaí (AMFRI), which resulted in a study population of 809 individuals. Having defined this population, the sample size for a field survey was calculated and, with a 5.92 percent margin of error, 211 entrepreneurs were interviewed. The sampling technique employed was simple, random and probabilistic.

The field survey was conducted between September and October of 2014 and was continued until the sample size previously defined was reached. Data collection was conducted using questionnaires divided into two sections with different objectives: the first was to investigate the presence of the entrepreneurial competencies defined by Cooley (1990). This section comprises thirty statements that reflect behavior patterns, three for each of the ten competencies. For each of these statements respondents could choose between the response options (1) never, (2) rarely, (3) sometimes, (4) almost always and (5) always. The respondents' answers are scored on a scale from 1 to 5 , resulting in a minimum score of three and a maximum score of fifteen points for each of the entrepreneurial competencies, and in order to consider a competence present in the entrepreneur's behavior, the total score had to fall within the range of 12 to 15 points, based on work published by Lenzi (2008).

The second section of the questionnaire tested strategic behavior, according to the typology by Miles and Snow (1978). Blageski Junior (2008) drew on work by Conant, Mokwa and Varadarajan (1990) to develop an instrument containing four statements on the way in which the organization adapts to environmental contingencies, each of which reflects on behavior patterns defined by Miles and Snow (1978). In order to satisfactorily study strategic behavior, it is important that the organization studied had been operating for a certain period of time, thereby facing a series of different environmental contexts and consequently the processes of response. Therefore, this part of the questionnaire was only administered to entrepreneurs who had been in business for at least 3 years, even if in an informal manner, before registering as an Individual Micro Entrepreneur - a subset of 169 respondents.

Before initiating the analysis procedures, data were exported to and organized in Microsoft Excel, which was used to produce the graphs and tables that describe the sample and will be presented in the next section. The data were then exported to Statistica 8.0 for the Analysis of Variance (ANOVA), which, according to Hair et al. (2009), is a method for testing for equality of means by analyzing the variances in the sample. This statistical procedure was used to compare mean scores for entrepreneurial competencies across the different strategic behavior types, with a cutoff of $p=0.05$ in all tests. Significant differences were investigated using Scheffe's post-hoc test, chosen because it is more conservative than other alternatives (Hair et al., 2009) and therefore, more often recommended and utilized. It should be pointed out that the prerequisites for using ANOVA were confirmed for all analyses using tests of normality of residuals and Levene's test of homogeneity of variance. Results are shown in the next section.

\section{RESULTS}

This section presents the results of analyses, starting with a description of the profile of the sample and then tracing the Individual Micro Entrepreneurs' entrepreneurial competencies and strategic behavior types.

In terms of gender distribution, 126(59.72 percent) of the entire sample of 211 respondents were female and 85 (40.28 percent) were male. Analysis by age showed that 86.73 percent 
of the respondents were from 21 to 50 years old, breaking down very evenly within that range, as follows: 21 to $30,28.91$ percent; 31 to $40,29.38$ percent; and 41 to $50,28.44$ percent. The respondents' educational level was also analyzed. It was observed that the majority of respondents had completed secondary education (58.29 percent). A small group of entrepreneurs had not completed primary education (5.21 percent) and another very small group had started a postgraduate course ( 0.95 percent), whereas the remaining 35.55 percent were distributed across the categories primary education complete, but secondary education not completed; higher education started, but not completed; and higher education degree completed.

The majority of the respondents (97.16 percent) operate in the tertiary sector of the economy (sales or services) and just 2.84 percent in manufacturing. The five most commonly reported activities account for 42.18 percent of the interviewees, as follows: Clothing Retail (32 businesses), Beauty Salons or Hairdressers (29 businesses), Clothes making, Sewing or Piecework (16 businesses), Craftwork (7 businesses) and Production of Sweet and Savory Foods ( 5 businesses).

For the purposes of presentation and discussion of the results, the entrepreneurial competencies will be assigned acronyms, for ease of viewing in graphs and tables. These acronyms are listed in Table 2, together with the mean scores and standard deviations for each entrepreneurial competence and their three component observable variables that were measured using the data collection instrument.

Of the ten entrepreneurial competencies, those that were possessed by the largest number of entrepreneurs were PER and COM, both with 208 out of 211 respondents ( 98.58 percent), followed by DEQ, $206-97.63$ percent and ISC, $179-84.83$ percent. Other competencies possessed by more than 70 percent of the Individual Micro Entrepreneurs in the sample were INS, in 83.41 percent, SPM in 80.09 percent, OSI in 75.36 percent, and PEN in 74.41 percent. Competencies possessed by fewer respondents were CRT, with just 64.93 percent of the interviewees, and GOS with 59.20 percent of the sample.

It can be observed that the competencies CRT and GOS, which are the two possessed by fewest Individual Micro Entrepreneurs, also have the two observable variables with the lowest mean scores of the entire set of thirty variables. The mean score of 3.403 for the CRT variable "Is willing to take risks" indicates that these entrepreneurs have little appetite for risk, despite this being inherent to the entrepreneurial activity.

The mean score of 3.374 for the GOS variable "Sets goals that can be measured" indicates that these entrepreneurs have problems setting measurable targets for their objectives. Another GOS variable "Defines own goals", has a higher mean score, of 4.521, demonstrating that these entrepreneurs do set objectives, but do not transform them into indicators that can be tracked in a measurable manner.

The highest mean scores for observable variables were as follows: (DEQ2), "Is recognized for providing customer satisfaction" at 4.929; (PER3) "Accepts responsibility for actions as an entrepreneur" with 4.919; and (COM1) "Completes tasks within the conditions established, honoring commitments to customers and partners", with a mean score of 4.910.

Colley's ten entrepreneurial competencies (1990) are divided into three groups, named the Achievement Cluster, which contains competencies OSI, CRT, DEQ, PER and COM; the Planning Cluster, comprising the competencies INS, GOS and SPM; and the Power Cluster, with the competencies PEN and ISC. In the sample studied here, Achievement Cluster competencies have the highest mean score (13.70), followed by the Planning Cluster (12.88) and the Power Cluster (12.86). The higher mean for the Achievement Cluster was expected, since the three competencies with greatest frequency among the entrepreneurs (PER, COM, and DEQ) are all in this cluster. 
Table 2. Mean Scores for Observable Variables of Each Competence.

\begin{tabular}{|c|c|c|}
\hline Observable variables & Mean & SD \\
\hline (OSI) - Opportunity Seeking and Initiative & 13.095 & 1.109 \\
\hline (OSI1) - Creates, reinvents, or sells new products or services. & 4.133 & 0.838 \\
\hline (OSI2) - Takes innovation initiatives, creating new business. & 4.427 & 0.649 \\
\hline (OSI3) - Produces results from business opportunities identified in the market. & 4.536 & 2.198 \\
\hline (CRT) - Calculated Risk Taking & 12.213 & 0.735 \\
\hline (CRT1) - Evaluates the risk of own actions using information collected. & 4.417 & 0.738 \\
\hline (CRT2) - Acts to reduce the risk of these actions. & 4.393 & 1.318 \\
\hline (CRT3) - Is willing to take risks. & 3.403 & 2.097 \\
\hline (DEQ) - Demand for Efficiency and Quality & 14.052 & 0.724 \\
\hline (DEQ1) - Activities are very innovative and increase quality and efficiency of processes. & 4.256 & 0.292 \\
\hline (DEQ2) - Is recognized for providing customer satisfaction. & 4.929 & 0.469 \\
\hline (DEQ3) - Sets deadlines and meets them and quality standards. & 4.867 & 0.996 \\
\hline (PER) - Persistence & 14.621 & 0.392 \\
\hline (PER1) - Acts to overcome obstacles when they arise. & 4.867 & 0.513 \\
\hline $\begin{array}{l}\text { (PER2) - Does not give up in unfavorable situations and finds ways to achieve } \\
\text { objectives. }\end{array}$ & 4.834 & 0.306 \\
\hline (PER3) - Accepts responsibility for actions as an entrepreneur. & 4.919 & 0.850 \\
\hline (COM) - Commitment to the Work Contract & 14.536 & 0.333 \\
\hline $\begin{array}{l}\text { (COM1) - Completes tasks within the conditions established, honoring commitments to } \\
\text { customers and partners. }\end{array}$ & 4.910 & 0.730 \\
\hline (COM2) - When necessary, "pitches in" to get a job done. & 4.725 & 0.300 \\
\hline (COM3) - Wants to maintain customer satisfaction and does so. & 4.900 & 0.917 \\
\hline (INS) - Information Seeking & 13.592 & 0.767 \\
\hline (INS1) - Personally seeks the information needed for a project. & 4.578 & 0.818 \\
\hline (INS2) - Personally investigates new processes or innovative ideas. & 4.460 & 0.799 \\
\hline (INS3) - When necessary, consults specialists for help with activities. & 4.555 & 1.835 \\
\hline (GOS) - Goal Setting & 11.938 & 0.853 \\
\hline (GOS1) - Defines own goals. & 4.521 & 0.948 \\
\hline (GOS2) - Sets clear and specific goals. & 4.043 & 1.162 \\
\hline (GOS3) - Sets goals that can be measured. & 3.374 & 2.479 \\
\hline (SPM) - Systematic Planning and Monitoring & 13.085 & 0.729 \\
\hline (SPM1) - Makes plans with well-defined and clear tasks and deadlines. & 4.573 & 0.990 \\
\hline (SPM2) - Constantly revises own plans. & 4.431 & 0.920 \\
\hline (SPM3) - Takes daring decisions. & 4.081 & 1.979 \\
\hline (PEN) - Persuasion and Networking & 12.754 & 0.954 \\
\hline $\begin{array}{l}\text { (PEN1) - Is able to influence other people to become partners in projects and to acquire } \\
\text { the resources needed to achieve objectives. }\end{array}$ & 3.863 & 0.866 \\
\hline (PEN2) - Is able to use key people to achieve results. & 4.128 & 0.610 \\
\hline (PEN3) - Develops and strengthens relationships network. & 4.763 & 2.032 \\
\hline (ISC) - Independence and Self-confidence & 12.962 & 1.015 \\
\hline (ISC1) - Is willing to break rules and barriers that are deep-rooted in the market. & 4.062 & 0.712 \\
\hline (ISC2) - Trusts own judgment and sticks to it even in the face of opposition. & 4.085 & 0.506 \\
\hline (ISC3) - Has confidence in own actions and faces challenges without fear. & 4.815 & 1.527 \\
\hline
\end{tabular}

(OSI3) - Produces results from business opportunities identified in the market.

2.198

(CRT) - Calculated Risk Taking

(CRT2) - Acts to reduce the risk of these actions.

$4.417 \quad 0.738$

(CRT3) - Is willing to take risks.

$3.403 \quad 2.097$

(DEQ) - Demand for Efficiency and Quality

(DEQ1) - Activities are very innovative and increase quality and efficiency of processes.

$4.929 \quad 0.469$

(DEQ3) - Sets deadlines and meets them and quality standards.

(PER) - Persistence

(PER2) - Does not give up in unfavorable situations and finds ways to achieve objectives.

(COM) - Commitment to the Work Contract
(COM1) - Completes tasks within the conditions established, honoring commitments to customers and partners.

0.300

(COM3) - Wants to maintain customer satisfaction and does so.

(INS1) - Personally seeks the information needed for a project.

(INS2) - Personally investigates new processes or innovative ideas.

$4.460 \quad 0.799$

(INS) - When necessary, consults specialists for help with activities.

(GOS1) - Defines own goals.

(SPM) - Systematic Planning and Monitoring

(SPM2) - Constantly revises own plans.

$4.431-0.920$

(SPM3) - Takes daring decisions.

3.863

866

the resources nit

$4.128 \quad 0.610$

2.032

$4.062 \quad 0.712$

$4.085-0.506$

Source: Author's elaboration. 
BBR

16,3

Another analysis was performed to identify the number of competencies possessed by each entrepreneur and 81.50 percent of the entrepreneurs stated they had at least 7 developed entrepreneurial competencies. This is a positive finding, since according to Ahmad et al. (2010), entrepreneurial competencies lead to a direct positive impact on commercial success.

It should be noted that tests were run to detect associations between the entrepreneurs' profiles (gender, age, educational level, and time in business) and the number of entrepreneurial competencies they possessed, but these analyses did not detect significant differences for any of the variables. Similar analyses were performed for the mean scores for each entrepreneurial competence, individually against the entrepreneur's profiles, and once more, there were no significant differences. It was therefore concluded that, at least for the sample studied here, the variables collected to trace the profiles of the entrepreneurs are not determinants of the number of entrepreneurial competencies possessed by them, nor of the mean scores for each competence.

With relation to the identification of strategic behavior types, the type with highest incidence was entrepreneurs with Prospector behavior (91 entrepreneurs, 53.85 percent). The second most common behavioral pattern was Defender (49 entrepreneurs, 28.99 percent), followed by Analyzers (21 entrepreneurs, 12.43 percent). The lowest incidence was for Reactive Entrepreneurs (4.73 percent, 8 entrepreneurs), confirming the findings of studies by Miles and Snow (1978), Blageski Junior (2008), and Gardelin (2010). Miles and Snow (1978) stated that firms that behave as Reactors have poor rates of survival in competitive markets and that this is one of the reasons they are detected in smaller numbers in studies, although this claim was not confirmed in some studies, such as those by Gimenez et al. (1999) and Ribeiro (2010).

Having identified the Individual Micro Entrepreneurs' entrepreneurial competencies and the strategic behaviors they adopt, subsequent analyses were designed to test for relationships between variables, in order to determine whether entrepreneurial competencies were linked with specific strategic behavior types (and if so, which competencies were related to which types), using the Analysis of Variance (ANOVA). When each of the ten entrepreneurial competencies were analyzed individually, we found that the presence of six of them (OSI, CRT, DEQ, GOS, SPM, ISC) did influence the strategic behavior adopted by the entrepreneurs, while for four of them (PER, COM, INS, PEN) there were no statistical differences that could support this conclusion. These results are shown in detail in Table 3.

For the OSI competence, there were differences both between Prospectors and Reactors and between Analyzers and Reactors. For the DEQ competence, the mean score for Reactors was different from the scores for all other behavioral types. For all of the other competencies that exhibited differences (CRT, GOS, SPM, and ISC), all differences were detected between Prospectors and Reactors.

Entrepreneurs with Prospector behavior exhibited significantly higher means for four of the six competencies (OSI, CRT, GOS, ISC). Entrepreneurs who were classed as Analyzers had higher means for two other competencies (DEQ and SPM). In the four competencies for which Prospectors had the highest means, Analyzers had the second highest values. Defenders had the third highest means for all of these competencies. In turn, Reactive Entrepreneurs had the lowest means for all six competencies with significant differences. This result is relevant with respect to both of the theories on which this study is founded.

Another analysis designed to detect relationships between the constructs confirmed the existence of differences between the number of entrepreneurial competencies possessed by each member of the sample and the strategic behavior they adopt, with an ANOVA p-value of 0.001074 . The Scheffé test showed that, in addition to the lower means already 
Table 3. Differences in Entrepreneurial Competencies Across Strategic Behavior Types.

\begin{tabular}{|c|c|c|c|}
\hline Competence & $\begin{array}{l}\text { Difference } \\
\text { between }\end{array}$ & $\begin{array}{l}\text { Significance } \\
\text { p-value }\end{array}$ & Mean \\
\hline \multirow{4}{*}{ Opportunity Seeking and Initiative (OSI) } & Prospector and & $0.008175^{* *}$ & 13.516 \\
\hline & Reactor & \multirow{3}{*}{$0.028163 *$} & 10.750 \\
\hline & Analyzer and & & 13.476 \\
\hline & Reactor & & 10.750 \\
\hline \multirow{2}{*}{ Risk Taking (CRT) } & Prospector and & \multirow[t]{2}{*}{$0.041929 *$} & 12.505 \\
\hline & Reactor & & 10.375 \\
\hline \multirow{6}{*}{ Demand for Efficiency and Quality (DEQ) } & Prospector and & \multirow[t]{2}{*}{$0.000052 * *$} & 14.187 \\
\hline & Reactor & & 12.500 \\
\hline & Analyzer and & $0.000038 * *$ & 14.429 \\
\hline & Reactor & \multirow{3}{*}{$0.001354 * *$} & 12.500 \\
\hline & Defender and & & 13.939 \\
\hline & Reactor & & 12.500 \\
\hline Persistence (PER) & \multicolumn{2}{|c|}{ Not significant } & \\
\hline Commitment to the Work Contract (COM) & \multicolumn{2}{|c|}{ Not significant } & \\
\hline Information Seeking (INS) & \multicolumn{2}{|c|}{ Not significant } & \\
\hline \multirow{2}{*}{ Goal Setting (GOS) } & Prospector and & $0.015456^{*}$ & 12.187 \\
\hline & Reactor & & 9.2500 \\
\hline \multirow{2}{*}{ Systematic Planning and Monitoring (SPM) } & Prospector and & $0.039053 *$ & 13.286 \\
\hline & Reactor & & 11.125 \\
\hline Persuasion and Networking (PEN) & \multicolumn{2}{|c|}{ Not significant } & \\
\hline \multirow{2}{*}{ Independence and Self-confidence (ISC) } & Prospector and & $0.022492 *$ & 13.264 \\
\hline & Reactor & & 11.625 \\
\hline
\end{tabular}

* Significance at $0.05 ; * *$ Significance at 0.01 .

Source: Author's elaboration.

detected, Reactors also had lower numbers of competencies than entrepreneurs classified as belonging to one of the other three behavior patterns. On average, Prospector entrepreneurs had 8.56 of the 10 competencies developed, Defenders had 7.97, Analyzers had 8.38, and Reactors had just 6 of those competencies. This result shows that entrepreneurs with a lower number of developed competencies tend to exhibit Reactor strategic behavior, an evidence that has relevant practical and theoretical implications, which will be discussed in the next section.

Once the entrepreneurs had been classified into four groups, according to the strategic behavior types they adopt, the percentage of participants with each of the competencies developed was calculated, by strategic behavior group. Analysis of frequencies reveals which competencies are most associated with each of Miles and Snow's (1978) strategic types. The competencies observed with highest frequency among Prospector entrepreneurs were OSU (83.52 percent) and CRT (70.33 percent); while DEQ (100.00 percent) was observed in all Analyzer entrepreneurs; PER was observed with equal frequency (100.00 percent) in both Analyzer and Defender participants; and COM was observed with equal frequency (100.00 percent) in Prospector, Defender, and Reactor entrepreneurs. The competence INS (90,48 percent) was most strongly associated with Analyzer behavior, GOS (63.74 percent) with Prospector types, and SPM (85.71 percent) and PEN (85.71 percent) were associated with Analyzers. Finally, ISC (93.41 percent) was most frequent among Prospectors. A framework was developed illustrating these relationships (Figure 1). 
BBR

16,3

\section{DISCUSSION}

The primary objective of this study was to establish a relationship between entrepreneurs' set of Entrepreneurial Competencies (COOLEY, 1990) and the Strategic Behavior (MILES; SNOW, 1978) they adopt in order to determine whether possession of these competencies would be linked with adoption of more consistent strategies. This section discusses the study results in terms of the four research questions posed earlier.

- Q1: Which competencies (and sets of competencies) are most present in the behavior of Individual Micro Entrepreneurs?

The results showed that PER, COM, DEQ, ISC, and INS were the five competencies most frequently observed in the entrepreneurs' behavior, all with rates exceeding 80 percent. The two competencies that were observed least frequently were CRT and GOS.

Ever since the writings of Cantillon (1755) and Say (1803), risk has been associated with the entrepreneur, who is faced with the uncertainty of achieving the desired return. A low appetite for risk may limit firms' growth and this finding in this sample could trigger further research into Individual Micro Entrepreneurs, analyzing their appetite for risk and the degree to which this affects the limits of growth of their firms, since it raises the question of whether the choice of this method of registering the firm in itself related to risk aversion.

With regard to setting goals, we found that these entrepreneurs do not transform their objectives into measurable targets and indicators and, consequently, they are unable to systematically monitor the results they are achieving in relation to these indicators. This difficulty is most clearly shown by the fact that the cluster of planning competencies, comprising INS, GOS and SPM, had a lower mean score (12.88) than the achievement cluster (13.70).

This shows that these entrepreneurs are more competent at identifying opportunities and mobilizing the resources needed to implement their ideas than they are at planning these actions, collecting information, and setting goals and making long-term action plans. While the capability to identify and exploit opportunities is the principal characteristic of entrepreneurs, a deficiency in planning activities can compromise firms' longevity, particularly in turbulent economic and social scenarios, such as that faced by Brazilian entrepreneurs. This finding is a cause for concern, since lack of planning is one of the principal causes of the demise of small businesses, according to Ferreira et al. (2011).

\section{- Q2: What strategic behavior do these entrepreneurs adopt?}

The results show that Prospector strategic behavior (53.85 percent) was the type most frequently adopted by entrepreneurs comprising the sample. These findings are positive, since the high incidence of prospective entrepreneurs shows that these interviewees seek opportunities in the market and strive to act as pioneers (Miles and Snow, 1978). In view of the intense competition faced in the great majority of markets, this is a characteristic that could be a determinant of business success. The Defenders, who exhibit the opposite strategic behavior to Prospectors, were the second most common type in the sample (29.17 percent), followed by entrepreneurs classed as Analyzers (12.50 percent). According to Gimenez et al. (1999), these three types of strategic behavior present superior performance indicators comparing to the Reactive firms, found less frequently in this study (4.73 percent of the sample), which coincides with the results of Miles and Snow (1978), Blageski Junior (2008) and Gardelin (2010). While the present study did not collect data on the performance of the entrepreneurs who were interviewed, the finding that 95.24 percent of them adopt strategies that can guide the firm to superior performance is a positive indicator. 
- Q3: Do higher mean scores for each competence and a larger set of developed competencies induce entrepreneurs to adopt more consistent strategic behavior?

The results demonstrate that there is indeed such a relationship in the sample studied, since analysis of the differences between mean scores for each competence against strategic behavior types led to the conclusion that six of the ten competencies were statistically different between different types. The great majority of these differences were observed between Prospector and Reactor behavior types. Of the six competencies with significantly different means, entrepreneurs Prospectors have higher values of four (OSI, CRT, GOS and ISC) and Analyzers for the other two (DEW and SPM). In cases where Prospectors means were higher, Analyzers had the second highest means, followed by Defenders. This fact can be explained by statements made by Gimenez et al. (1999) and Desarbo et al. (2005), who state that the behavior of Analyzers is a compromise between the characteristics of Prospectors and Defenders.

Reactor Entrepreneurs exhibited the lowest mean scores for all of the competencies, and the differences were significant. According to Miles and Snow (1978), firms that merely react to the external environment and act with no strategic consistency, lose out in competitiveness while Ahmad (2010), claim that performance of micro and small businesses is strongly influenced by the entrepreneur's competencies. The reflection that emerges from these analyses is: Can Reactive Entrepreneurs and Entrepreneurs who do not possess developed entrepreneurial competencies compete in the market to a degree that their firms will remain competitive and profitable over the long term?

Another indicator of the existence of the relationship between the constructs is that Reactors possessed an average of 6 entrepreneurial competencies, whereas Defenders had 7.97, Analyzers had 8.38, and Prospectors possessed 8.56 of them. The results are shown in Table 4. This result provides evidence that entrepreneurs with a lower number of developed competencies tend to exhibit Reactor strategic behavior, which is an inconsistent strategy. This finding has relevant practical and theoretical implications, and is in line with statements made by Mitchelmore and Rowley (2010) and Sánchez (2012). If the objective is to reduce as far as possible the number of entrepreneurs who merely react to the environment, one feasible option would be to implement actions and policies that develop Entrepreneurial Competencies in people who already have or plan to start their own businesses.

Table 4. Scheffé test for mean number of competencies by strategic behavior type.

\begin{tabular}{lcccc}
\hline EC & $\{1\} 8.5615$ & $\{2\} 7.9796$ & $\{3\} 6.0000$ & $\{4\} 8.3810$ \\
\hline Prospectors & & 0.386818 & $0.001966^{* *}$ & 0.991304 \\
Defenders & 0.386818 & & $0.032878^{*}$ & 0.852524 \\
Reactors & $0.001966^{* *}$ & $0.032878^{*}$ & & $0.014120^{*}$ \\
Analyzers & 0.991304 & 0.852524 & $0.014120^{*}$ & \\
\hline
\end{tabular}

* Significance at $0.05 ; * *$ Significance at 0.01 .

Source: Author's elaboration.

- Q4: Which entrepreneurial competencies are associated with each of the strategic behavior types?

The findings also allow concluding that certain entrepreneurial competencies are more frequently found linked with certain strategic behavior types. The competencies OSI, CRT, COM, GOS, and ISC are more frequently possessed by Prospectors. The competencies DEQ, PER, INS, SPM, and PEN are more strongly associated with Analyzers, the competencies PER and COM are also observed in Defenders, and Reactors are most likely 
to possess COM. The information in Table 5 demonstrates the percentage of individuals with each of the ten entrepreneurial competencies present for the four groups of strategic behavior, revealing the competencies most closely associated with each of the Miles and Snow (1978) standards.

Table 5. Percentage of individuals with each entrepreneurial competence present per group of strategic behavior.

\begin{tabular}{lcccc}
\hline Entrepreneurial & \multicolumn{4}{c}{ Strategic Behavior } \\
\cline { 2 - 5 } Competencies & Prospector & Analyzer & Defender & Reactor \\
\hline OSI & $83.52 \%$ & $76.19 \%$ & $67.35 \%$ & $50.00 \%$ \\
CRT & $70.33 \%$ & $61.90 \%$ & $67.35 \%$ & $25.00 \%$ \\
DEQ & $98.90 \%$ & $100.00 \%$ & $97.96 \%$ & $75.00 \%$ \\
PER & $98.90 \%$ & $100.00 \%$ & $100.00 \%$ & $87.50 \%$ \\
COM & $100.00 \%$ & $95.24 \%$ & $100.00 \%$ & $100.00 \%$ \\
INS & $85.71 \%$ & $90.48 \%$ & $79.59 \%$ & $75.00 \%$ \\
GOS & $63.74 \%$ & $57.14 \%$ & $53.06 \%$ & $25.00 \%$ \\
SPM & $82.42 \%$ & $85.71 \%$ & $73.47 \%$ & $62.50 \%$ \\
PEN & $74.73 \%$ & $85.71 \%$ & $77.55 \%$ & $37.50 \%$ \\
ISC & $93.41 \%$ & $85.71 \%$ & $81.63 \%$ & $62.50 \%$ \\
\hline
\end{tabular}

Source: Author's elaboration.

Figure 1 contains a schematic illustration of these relationships, showing which entrepreneurial competencies are most associated with each of the strategic behavior types, providing new evidence that an entrepreneur's set of entrepreneurial competencies can influence the strategic behavior adopted.

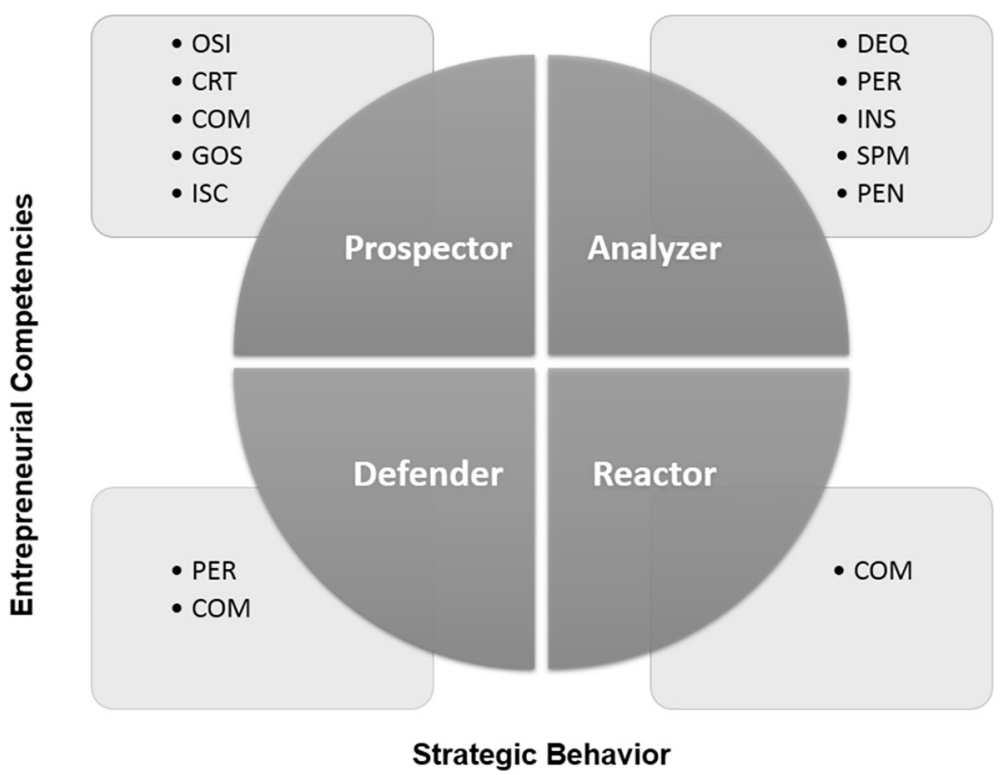

Figure 1. Relationships Between Entrepreneurial Competencies and Strategic Behavior.

Source: Author's elaboration. 
The fact that the competencies OSI and ISC were most strongly associated with Prospector behavior confirms the profile described by Miles and Snow (1978), who conceived this strategic posture as frequently seeking for opportunities in new products and/or markets, putting a premium on pioneering activities. Along the same lines, Analytical entrepreneurs had the highest mean scores for the competencies INS and SPM, which is also compatible with these authors' work, since this strategic profile is characterized by analysis of market tendencies and acquisition of information, and constant planning is a fundamental element.

However, some of the findings appear to contradict the strategic profiles as described by Miles and Snow (1978). This is the case of the competency CRT, for example, which was most associated with Prospector behavior in this study. Individuals who are Analyzers aim to minimize the risk involved in their actions, through information acquisition and planning. It was expected that this competence would be most strongly displayed by people who exhibit this behavior. Another result that diverges from the theoretical assumptions is that the competence DEQ was most strongly associated with Analyzer entrepreneurs, rather than Defenders, since it is members of the second group who are recognized as specializing in one area of activity, restricting themselves to what they do better than the competition and, therefore, concern for quality is essential. Finally, the fact that Reactor behavior was only associated with the competence COM is another indication that a larger set of competencies can induce an entrepreneur to adopt more consistent strategic behavior.

\section{CONCLUSIONS}

This study combines theories of entrepreneurial competencies and of strategic behavior, enriching the field of study with the finding that a larger set of competencies reduces the likelihood that entrepreneurs will adopt reactive strategic behavior with relation to adapting their firms to the environment. This is only a starting point on the path towards achieving an adequate depth of understanding of the relationship between characteristics of entrepreneurial behavior and organizational strategy.

This study's findings also have important implications for policies and practice. Entrepreneurship is one of the most important motors of socioeconomic development, since it makes the economy more dynamic and contributes to social wellbeing, through innovation in products and services that meet human needs. Therefore, promoting a culture that fosters entrepreneurship is essential, particularly for developing nations.

If it is clear that entrepreneurial competencies can contribute to more consistent strategic behavior and that these can be developed through training methods and by accumulation of experience, then implementation of public policies for training both incipient and established entrepreneurs should reduce the likelihood of small businesses failing and encourage a more entrepreneurial culture, especially in emerging countries.

Certain limitations notwithstanding, this study has fulfilled its objectives of attempting to understand the behavioral characteristics of Individual Micro Entrepreneurs and their relationship to the strategies they adopt. However, it is important to mention limitations related to the results. Possession of entrepreneurial competencies was measured using a self-report questionnaire completed by the entrepreneurs themselves. The use of crossreferencing with analyses involving their customers' perceptions, for example, would have enriched this study and provided a basis for comparing how the entrepreneurs self-evaluate and how they are evaluated. Another relevant point, and one that affects generalization of the results, is that the probabilistic sample studied did not take into account different strata of the population of Individual Micro Entrepreneurs. Using such strata, it would have been 
possible to take into consideration the same distributions of registered micro entrepreneurs in terms of sex, age, time since registration, and the cities and industries in which they do business, for example. Another limitation that should be noted is that the numbers of observations for entrepreneurs with behavior classed as Prospector (91), Defender (49), Analyzer (21), and Reactor (8) are unequal. Conducting Analysis of variance with equal numbers of observations would have increased the reliability of the study results.

As suggestions for future research, it is recommended that the relationship between entrepreneurs' behavioral characteristics and the strategies they adopt be investigated in greater depth, employing different typologies, data collection instruments, and statistical methods from those employed here, in order to collect more robust evidence on the relationships between entrepreneurial competencies and strategy, which could extend as far as conducting a hypothetical-deductive study to test the relationships suggested in this study. Entrepreneurial Competencies and Strategic Behavior could also be associated with firm performance. One final suggestion for further research relates to a field that has not been explored to any great extent in studies of entrepreneurship; i.e. firm mortality. The analyses would focus on whether (and in what ways) entrepreneurs' Entrepreneurial Competencies and Strategic Behavior could reduce the likelihood of their businesses failing. Studies along these lines would make a significant contribution to advancing this field of study.

\section{REFERENCES}

Ahmad, N.H., T. Ramayah, C. Wilson, and L. Kummerow. Is entrepreneurial competency and business success relationship contingent upon business environment? A study of Malaysian SMEs. International Journal of Entrepreneurial Behavior \& Research, v. 16, n. 3, p. 182-203, 2010.

Andrews, R., G.A. Boyne, K.J. Meier, L.J. O’TOOLE and, R. M. Walker. Strategic Fit and Performance: A Test of the Miles and Snow Model. In: Conference on Organizational Strategy, Structure, and Process: A Reflection on the Research Perspective of Miles and Snow. 2008.

Astley, W. G. and, A. H. Van de Ven. Debates e perspectivas centrais na teoria das organizações. Revista de Administração de Empresas, v. 45, n. 2, p. 52-73, 2005.

Bamiatzi, V., S. Jones, S. Mitchelmore and, K. Nikolopoulos. The role of competencies in shaping the leadership style of female entrepreneurs: the case of north west of England, Yorkshire, and North Wales. Journal of Small Business Management, v. 53, n. 3, p. 627-644, 2015.

Blageski Junior, E. J. Comportamento estratégico, monitoramento do ambiente e desempenho em pequenas empresas varejistas de veículos. Master Dissertation, Universidade do Vale do Itajaí.

Cancellier, E. L. P. L. O monitoramento de concorrentes na pequena empresa: um estudo de caso em empresa catarinense. Contextus-Revista Contemporânea de Economia e Gestão, v. 11, n. 1, p. 25-38, 2013.

Cantillon, R. Essai sur la nature du commerce en general. Institut National d'Etudes Démographiques. 1755.

Chell, E. CHELL, Elizabeth. Review of skill and the entrepreneurial process. International Journal of Entrepreneurial Behavior \& Research, v. 19, n. 1, p. 6-31, 2013.

Cooley, L. COOLEY, Lawrence. Entrepreneurship training and the strengthening of entrepreneurial performance. Final Report. Contract No. DAN-5314-C-00-3074-00. Washington: USAID, 1990.

DeSarbo, W. S., C.A. Di Benedetto, and, I. Sinha. DESARBO, Wayne S.; ANTHONY DI BENEDETTO, C.; SINHA, Indrajit. Revisiting the Miles and Snow strategic framework: uncovering interrelationships between strategic types, capabilities, environmental uncertainty, and firm performance. Strategic Management Journal, v. 26, n. 1, p. 47-74, 2005.

DeSarbo, W. S., A.C. Di Benedetto, and M. Song. Evaluating SBU Heterogeneity: Comparing the Miles and Snow Strategic Framework Against Alternative Quantitative Modeling Approaches. In: Organizational Strategy, Structure, and Process: A Reflection on the Research Perspective of Miles and Snow, conference co-sponsored by Cardiff University and the Economic and Social Research Council, Cardiff, Wales. 2008.

Feuerschütte, S. G. and, C.K. Godoi. FEUERSCHÜTTE, Simone Ghisi; GODOI, Christiane Kleinübing. Competências de empreendedores hoteleiros: um estudo a partir da metodologia da história oral. TurismoVisão e Ação, v. 10, n. 1, p. 39-55, 2008.

Fleury, M. T. L. and, A. Fleury. Construindo o conceito de competência. Revista de administração contemporânea, v. 5, n. SPE, p. 183-196, 2001. 
Gallas, J. C., Cancellier, É. L. P. L., Vargas, S. M. L., and, Rossetto, C. R. Comportamento Estratégico no Setor de Beleza e Estética Baseado na Tipologia de Miles e Snow. Revista Organizações em Contexto, 11(22), 119-141, 2015.

Gardelin, J. P., Rossetto, C. R., and Verdinelli, M. A. O relacionamento entre a incerteza ambiental e o comportamento estratégico na percepção dos gestores de pequenas empresas. Revista de Administração, 48(4), 702-715, 2013.

Ghobril, A. N. and R. G. Moori. Alinhamento estratégico entre indústrias de bens de capital e de alimentos: uma análise com base em Miles \& Snow. Gestão \& Regionalidade, v. 25, n. 73, 2009.

Gimenez, F. A., C. Pelisson, E.G. Krüger, and, P. Hayashi Jr. Estratégia em pequenas empresas: uma aplicação do modelo de Miles e Snow. Revista de administração contemporânea, v. 3, n. 2, p. 53-74, 1999.

Hair, J. F., Black, W. C., Babin, B.J., Anderson, R.E. and Tatham, R.L. Análise multivariada de dados. Porto Alegre, RS: Bookman Editora, 2009.

Jain, R. K. Entrepreneurial competencies: a meta-analysis and comprehensive conceptualization for future research. Vision, v. 15, n. 2, p. 127-152, 2011.

Le Boterf, G. Desenvolvendo a competência dos profissionais. Porto Alegre, RS: Artmed, 2003.

Lenzi, F. C. Os empreendedores corporativos nas empresas de grande porte dos setores mecânico, metalúrgico e de material elétrico/comunicação em Santa Catarina: um estudo da associação entre tipos psicológicos e competências empreendedoras reconhecidas, Doctoral Thesis, Universidade de São Paulo, 2008.

Lizote, S.A. and, M. A. Verdinelli. Competências empreendedoras: um estudo com funcionários administrativos de uma empresa do ramo alimentício. Revista Pensamento Contemporâneo em Administração, v. 8, n. 1, 2014.

Martins, L. A. V. and, Flores, L. C. D. S. Comportamento estratégico dos gestores hoteleiros do Vale do Itajaí/ Santa Catarina. Revista Hospitalidade, 14(2), 01-23, 2017.

McClelland, D. C. Achievement-motivation can be developed. Harvard business review, v. 43, n. 6, p. 6-\&, 1965.

McClelland, D. C. N achievement and entrepreneurship: A longitudinal study. Journal of personality and Social Psychology, v. 1, n. 4, p. 389, 1965.

Middleton, K.W. and, A. Donnellon. Personalizing entrepreneurial learning: A pedagogy for facilitating the know why. Entrepreneurship Research Journal, v. 4, n. 2, p. 167-204, 2014.

Miles, R. E., C.C. Snow, A. D. Meyer and, H.J. Coleman. Organizational strategy, structure, and process. Academy of management review, v. 3, n. 3, p. 546-562, 1978.

Mitchelmore, S. and, J. Rowley. Entrepreneurial competencies: a literature review and development agenda. International journal of entrepreneurial Behavior \& Research, v. 16, n. 2, p. 92-111, 2010.

Nassif, V. M. J., T. Andreassi, and, F. Simões. Competências empreendedoras: há diferenças entre empreendedores e intraempreendedores?. RAI Revista de Administração e Inovação, v. 8, n. 3, p. 33-54, 2011.

Parnell, J.A. Uncertainty, generic strategy, strategic clarity, and performance of retail SMEs in Peru, Argentina, and the United States. Journal of Small Business Management, v. 51, n. 2, p. 215-234, 2013.

Say, J. B. A Treatise on Political Economy or the Production, Distribution and Consumption of Wealth. New York, NY: Augustus M. Kelley, 1803.

SÁNCHEZ, J. The influence of entrepreneurial competencies on small firm performance. Revista Latinoamericana de Psicología, v. 44, n. 2, p. 165-177, 2012.

SARWOKO, E. Growth strategy as a mediator of the relationship between entrepreneurial competencies and the performance of SMEs. Journal of Economics, Business \& Accountancy, v. 19, n. 2, p. 219-226, 2016.

Schumpeter, J. A. Change and the entrepreneur: Postulates and patterns for entrepreneurial history. Cambridge, MA: Harvard University Press, 1949.

Souza, M. A. M. and Teixeira, R. M. Competências empreendedoras em franquias: estudo de multicasos em Sergipe. REGEPE-Revista de Empreendedorismo e Gestão de Pequenas Empresas, v. 2, n. 2, p. 3-31, 2013.

Walker O.C. Jr, H.W. Boyd Jr, J. Mullins and Larréché, J.C. Marketing Strategy: Planning and Implementation. Homewood, IL: Irwin/McGraw-Hill, 2003.

Zampier, M. A. and, A. R. W. Takahashi. Competências empreendedoras e processos de aprendizagem empreendedora: modelo conceitual de pesquisa. Cadernos Ebape. BR, v. 9, 2011.

Zarafian, P. O modelo da competência: trajetória histórica, desafios atuais e propostas. São Paulo, SP: Editora Senac, 2004. 